\title{
Biblical Etymology of Earthly Branches and Jesus Christ
}

\author{
James Xianxing Du
}

1412 Ansel Road, Cleveland, OH 44106, United States of America

Email address: $\quad$ xx1du@yahoo.com shen1andian@163.com

\begin{abstract}
Earthly branch is a major ancient Asian calendar system composed of twelve branches. This article allocates the etymology of earthly branches to biblical events of Jesus, indicating bible as the semantic origin of this mysterious calendar. The twelve branches match twelve events on the biblical day of Jesus' crucifixion from last supper to sacrifice on cross, with each branch equal to two hours of the day in a continuous cycle. In addition, these branches match Abraham's two sons, exhibiting dual etymology to both old and new testaments.
\end{abstract}

\section{Keywords}

Jesus Christ, earthly branch calendar, etymology, bible, culture

\section{Introduction}

Genesis claims that ancient languages were divinely created, and Asian heavenly stem calendar system apparently matches the seven divine days of Genesis (Moses 2nd millennium B.C.a, Du 2019a). Besides heavenly stem, there is another major calendar system, termed twelve earthly branches, routinely used in China and neighboring countries for several millenniums. These earthly branches represents twelve intervals of a day, with each branch equal to two hours (https://en.wikipedia.org).

For millenniums, various hypotheses have been proposed on the origin and meaning of this mysterious calendar system (Xu 100-121 A.D.), but no consensus has been reached. In this article, we present biblical linguistic evidence that twelve earthly branches are predestinedly designed to match Jesus Christ. They also match biblical sons of Abraham.

\section{Methods}

The twelve words of earthly branches in the language of China are analyzed to match relevant biblical events in a systematic manner. In addition, linkage analysis interconnects these branches and related words to match biblical etymology.

\section{Results}




\subsection{The first branch 子 Son of man}

The first earthly branch 子 (ancient writing as 7 ), meaning son or man in dictionary, represents 23:00-1:00 midnight in earthly branch calendar, when the arrested Jesus claimed Himself again as Son in "the courtyard of the high priest". In Mark 14:61-62, when again the high priest asked Him whether He was Son of GOD, "I Am," said Jesus, "And you will see The Son of Man sitting at THE RIGHT HAND OF THE MIGHTY ONE and coming on the clouds of heaven." Although it lasted several hours without interrogating out Bethlehem as the prophesied birth city, it is the exact reason that two branches, 子 and 亥 (21:00-23:00, Section 3.12), both represent Son as Child 孩.

子 can also match the birth night when Jesus was visited by shepherds. "So they hurried off and found Mary and Joseph, and The Baby, Who was lying in the manger." It must be pointed out that Son of GOD and Son of Man/man (Jesus was also in human flesh as adopted Son of Joseph) do not mean that GOD is Man/man, in analogy to the fact that GOD is not Joseph, although Jesus is Son of Joseph (listed in the genealogy of Luke 3:23 "He was The Son, so it was thought, of Joseph") and Son of GOD. Although Adam is son of GOD in Luke $3: 38$ and Jesus is Son of GOD, Adam is not Jesus.

子 represents Son of Man, son or man, but always has biblical etymology in words. 籽/ 秄 seed has cereal 米/禾 and son/descendant 子, because in Genesis 1:28-8:22 “Be fruitful and increase in number", "I give you every seed-bearing plant on the face of the whole earth and every tree that has fruit with seed in it", and "as long as the earth endures, seedtime and harvest, cold and heat, summer and winter, day and night will never cease". 籽/秄 seed has Son of man 子, as in Matthew 13:11-17:21 and Mark 4:11-32 Jesus preached the parable of seed as a secret of the kingdom of heaven. Who "received the seed that fell on good soil is the man who hears the word and understands it. He produces a crop". "The kingdom of heaven is like a man who sowed good seed in his field." "The kingdom of heaven is like a mustard seed”. 芥荡 mustard has man 个 to be separated to the left and right ). Mustard seed 芥菜 籽 has 子采人, Son (子) to pick (采) man (人).

子 Boy is buoyant 浮 due to Jesus' walking on water in Matthew 14:25-31, and 子 boy is buoyant 浮 due to baby basket of Moses on Nile river (Moses 2nd millennium B.C.b). 乳㔜 milk has 爪 hand, 子 son and 2 water, as Moses had nursing mother. Milk has m as milk and kil as child. 稃 chaff has Son/man 子, hand and grain 禾, as in Luke 6:1 and Mark 2:1 “One Sabbath Jesus was going through the grainfields, and His disciples began to pick some heads of grain, rub them in their hands and eat the kernels."

Son 子 is in 孟, the eldest brother as firstborn, because of last supper's bitter cup 皿. (III) of Own (自) Blood 血, after Jesus claimed in Mark 3:32-35 and Matthew 12:47-50 "Whoever does GOD'S WILL is My brother and sister". 艋 boat is a related word, as in Matthew 8:23-15:39, Mark 3:8-6:54, Luke 8:22-37 and John 6:16-24 "He got into the boat and His disciples followed Him". "They went across the lake to the region of the Gerasenes. When Jesus got out of the boat, a man with an evil spirit came from the tombs to meet Him. This man lived in the tombs, and no one could bind him", so that 猛 (sudden or fierce force) is also related. The left of this word is the affix of animal, since the attached spirit was driven out to pigs. 猛's additional etymology includes sudden action to bleed offering's blood to a worshiping utensil by a man. 蜢 grasshopper was a clean insect 虫 editable by any man 子 of Numbers 13:33, who claimed that "we seemed like grasshoppers" to Nephilim and worshiped 
with utensil II , similar to locust eaten by John or before the tenth plague on Pharaoh's firstborn.

\subsection{The second branch $\nexists$ for the arrested}

The second earthly branch \# \# means to tie (as represented by /) hand ₹, and represents 1:00-3:00 at night when Jesus was already under arrest, as described in Matthew 26:47-56, Mark 14:43-52, Luke 22:54 and John 18:3-24. "Then the detachment of soldiers with its commander and the Jewish officials arrested Jesus. They bound Him and brought Him first to Annas". "Then Annas sent Him, still bound, to Caiaphas the high priest". 丑 also means ugly, not to go freely or not to offer by hand (gu is go or move), when Son's imprisonment was an ugly event. A also represents prohibition of Peter's hand to sword after Jesus' demand in John 18:11. "Put your sword away! Shall I not drink the cup THE FATHER has given Me?" The whole night when Jesus was detained, Peter never wielded sword again with his hands.

\subsection{The third branch 宙 for courtyard}

The third earthly branch 臼 represents 3:00-5:00 when Jesus was within courtyard represented by the affix of building $\nrightarrow$ or $\curvearrowleft$. $\uparrow$ or $\perp$ represents the direction or fire $火$ ' 18:15-27, "when they had kindled a fire in the middle of the courtyard and had sat down together, Peter sat down with them". "As Simon Peter stood warming himself, he was asked".

In additional interpretation, 函 has holy residence $\frown$, hands in worship $\in \exists$, and $\alpha$ starlight-guided direction of Magi, as "the star they had seen in the east went ahead of them until it stopped over the place where The Child was. When they saw the star, they were overjoyed. On coming to the house, they saw The Child with His mother Mary”. 星 star has birthday 生日, and birth 诞 has to stop 止, as this star stopped over Jesus' house. Moreover,

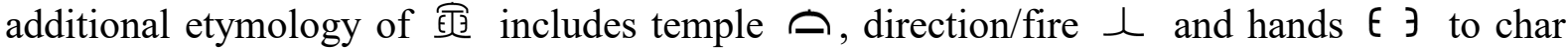
offering, because in Luke 2:22-24 "When the time of their purification according to the Law of Moses had been completed, Joseph and Mary took Him to Jerusalem to present Him to THE LORD (as it is written in the Law of THE LORD, "Every firstborn male is to be consecrated to THE LORD"), and to offer a sacrifice in keeping with what is said in the Law of THE LORD: "a pair of doves or two young pigeons."' In Leviticus 12:1-7, "If she cannot afford a lamb, she is to bring two doves or two young pigeons, one for a burnt offering and the other for a sin offering", indicating that Joseph and Mary had not received Magi's treasures when presenting Jesus at the temple after His circumcision, so that Magi's visit must have occurred after Jesus' birth night. After the star emerged, it took time for Magi to reach Jerusalem, meet Herod, travel to Bethlehem, and visit The Infant with financial gifts. Infant's translation 嬰 has duplicated affix of wealth 貝, related in etymology to finance 財, fiance Joseph and fiancee Mary, because of the costly gold and incense from Magi. However, "having been warned in a dream not to go back to Herod, they returned to their country by another route". Out of fury, Herod killed all boys under two in Bethlehem, a reason why Mary did not tell birthplace of Jesus before crucifixion, leading chief priests to misjudgment.

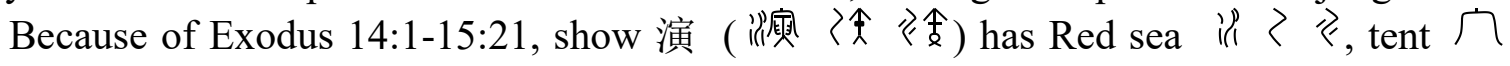
and worshiper's hands $\in$ $\exists$. "Tell the Israelites to turn back and encamp near Pi Hahiroth, between Migdol and the sea. They are to encamp by the sea". "Miriam the prophetess, 
Aaron's sister, took a tambourine in her hand, and all the women followed her, with tambourines and dancing." This cinema of Miriam's dance was near ocean after the marine

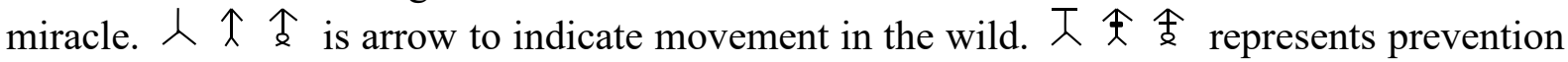
of return to Egypt, or inhibition of Pharaoh's horsemen to cross the sea, paused when Israelites encamped at either side of the sea. Alternatively, $\rightleftharpoons$ represents sanctuary mentioned in Exodus 15:17 for the people to be brought to 人, when "I will sing to THE LORD" and Miriam sang: "Sing to THE LORD, for HE IS HIGHLY EXALTED. The horse and its rider HE has hurled into the sea."

\subsection{The fourth branch 印 for exiting courtyard after rooster crowed}

The fourth earthly branch 印 (ancient versions 犵犵非), 5:00-7:00 after rooster crowed, is to pass through in etymology, and represents the hours Peter and Jesus exiting courtyard after rooster crowed three times. In Matthew 26:74-75, Mark 14:71-72 and Luke 22:61-62, "Immediately a rooster crowed". "Peter remembered The Word The Lord had spoken to him: "Before the rooster crows today, you will disown me three times." And he went outside and wept bitterly." Related to arrest in etymology, 雞 rooster has an avian affix 隹, and 爪 hand, oo 幺 chain and ster 大 Man/man to form 奚 arrest (Du, 2019a), because of Jesus' arrest at the night in Matthew 26:50-27:2, Mark 15:1 and John 18:12. They "seized Jesus and arrested Him", "bound Him", and "took Him" to high priest. Because of Jesus' Blood and crown, rooster has a scarlet cockscomb in the color of blood and crows. Cock crowed three times after the rock Peter disowned Christ three times. 昂 is star culturally associated with rooster and hour of its crowing in China and adjacent countries, because of Jesus Christ's crucifixion day.

印 can represent liquid to pass through, and hence also represents shedding blood to match Matthew 27:1-2, Mark 15:1 and Luke 22:66-23:1. "Very early in the morning, the chief priests, with the elders, the teachers of the law and the whole Sanhedrin, reached a decision. They bound Jesus, led Him away and handed Him over to Pilate" in order to murder Him, to let blood be on them. In Matthew 27:24-25, when Pilate "took water and washed his hands in front of the crowd. "I am innocent of This Man's Blood," he said. "It is your responsibility!" All the people answered, “His Blood is on us and on our children!"” 卯牛卯 羊 is to kill ox and lamb. After their conversation 仰, they pressed Pirate to 铆 nail Jesus onto cross. 鉚 is for metal 金 nail to pass through. Conversation has ear and is to sever and serve offering, with transverse voice through ear.

卯 can also shed blood of boys at Bethlehem. "When Herod realized that he had been outwitted by the Magi, he was furious, and he gave orders to kill all the boys in Bethlehem and its vicinity who were two years old and under." 柳 willow resembles blood flowing through and tears flowing to wail. 貿 trade has wealth 貝 to travel through gate, or shedding blood of offering at altar. 貝 initially meant offering split to two.

卵 非 egg has two eggs passing through an opening to lay eggs, and thus has eg and ge to go through. The other translation of egg 蛋 also has the affix to go 走. 孵非管 hatch is to $\pi$ catch egg 卵 or the young 子 by a man, as in Deuteronomy 22:6-7 "If you come across a bird's nest beside the road, either in a tree or on the ground, and the mother is sitting on the young or on the eggs, do not take the mother with the young. You may take the young, but be sure to let the mother go". Coincidentally, 卯's bronze and bone versions $)(l$ also resembles 
two pregnant women with big bellies in side view, when pregnant Mary met pregnant Elizabeth to talk 仰 in Luke 1:24-38, for voice to walk through their ears 耳.

卯 was also interpreted in 《Analytical Dictionary of Characters》 as heavenly gate (Xu 100-121 A.D.), and can match Jesus' empty tomb. [ ] 〈〉〈〉 represent the entrance of empty tomb. $x \times$ represent going into or out of tomb. In John 20:1-10, "Early on the first day of the week, while it was still dark, Mary Magdalene went to the tomb and saw that the stone had been removed from the entrance." "So Peter and the other disciple started for the tomb. Both were running, but the other disciple outran Peter and reached the tomb first." In Luke 24:1-12 and Mark 16:2-8, "very early in the morning, the women took the spices they had prepared and went to the tomb. They found the stone rolled away from the tomb, but when they entered, they did not find the body of The Lord Jesus." 窟 cave has 屈 wrongfully treated Body 尸 to come out 出 of cave 穴, as 屈 means the innocent to be wronged.

\subsection{The fifth branch 辰 for humiliation outside courtyard}

The fifth earthly branch 辰 represents 7:00-9:00 of Jesus' crucifixion day, when persecutors, guards or military soldiers humiliated 辱 Son in that morning 晨 in a series of events, before "the governor's soldiers took Jesus into the Praetorium and gathered the whole company of soldiers around Him. They stripped Him and put a scarlet robe around Him, and then twisted together a crown of thorns and set it on His Head" to "mocked Him" as described in all four gospel books. 辰 巵 initially meant not (as represented by -) to $\mathbb{E}$ step to a restricted place such as tabernacle $\digamma$ (Du 2020), and represents not to be in courtyard, because Jesus had been brought out of the courtyard. Thus, the three location-related branches 寅, 卯 and 辰 all match the chronological order of Jesus' crucifixion day.

蔑 (旁), to despise, has $¥ \Vdash$ Lamb, 四 eye and guard 戍, who despised Him. In addition, $+t$ (currently identical in morphology to the affix of grass or plant $\#$ ) can also represent thorn or hyssop. Later in John 19:29 "they soaked a sponge in it, put the sponge on a stalk of the hyssop plant, and lifted it to Jesus' lips”. 夢 夢 dream has ram ${ }^{\star}$, because in Matthew 1:20 dream involved Mary and Lamb of GOD when Joseph was instructed to 取 "take Mary home as your wife" to 娶 marry Mary. John 1:29 prophesied, "Look, The Lamb of GOD, Who takes away the sin of the world!"

As a major biblical etymology of dream, Abram's dream has ram $\aleph^{\prime}$, ? worshiper, $D$ meat, and $m$ as either eye or altar with division. D also represents 夕 sunset, as this dream was around sunset. In Genesis 15:9-21, “As the sun was setting, Abram fell into a deep sleep, and a thick and dreadful darkness came over him. Then THE LORD said to him, "Know for certain that your descendants will be strangers in a country". "Bring ME a heifer, a goat and a ram". "Abram brought all these to him, cut them in two". Thus, dream is for Abram to dice ram.

\subsection{The sixth branch $巳$ for Son Himself}

The sixth branch 巳 (古 bone version; \& bronze version; \& seal version) represents 9:00-11:00, the flogged and tortured Son Himself 己. In John 19:7, "We have a law, and according to that law He must die, because He claimed to be The Son of GOD". In Matthew 27:26-30, Mark 15:15 and John 19:1, "he had Jesus flogged, and handed Him over to be crucified", although in 1 Peter 2:24 "by His wounds you have been healed". 巳 also 
resembles gesture in worship 祀, as soldiers "paid homage to Him" and called out, "Hail, King of the Jews!” Again and again they struck Him.

\subsection{The seventh branch 午 for cross and darkness}

The seventh branch 午平平 means noon and represents 11:00-13:00, when darkness started to be over the land as printed in Luke 23:44-45 and Matthew 27:45. "It was now about noon, and darkness came over the whole land until three in the afternoon, for the sun stopped shining." $\uparrow$ represents blocked light, because here the dot or horizontal line is to block, and $\uparrow$ represents radiating sunlight. However, in other words it can be light from other stars. This is why 午 $\uparrow \uparrow$ means noon, because star light is not visible at noon, appearing to be blocked. This word matches the historical darkness before Jesus' sacrifice.

No matter whether darkness initiated by $1 \mathrm{pm}$, in alternative etymology 午 11:00-13:00 represents Jesus with cross and Simon who carried Jesus' cross, and currently has man (人) with cross (十), while its ancient version $\uparrow$ points to the direction of Golgotha. In Matthew 27:32-33 and Mark 15:21-24, "they met a man from Cyrene, named Simon, and they forced him to carry the cross. They came to a place called Golgotha". In Luke 23:26-31, "they seized Simon from Cyrene, who was on his way in from the country, and put the cross on him and made him carry it behind Jesus."

\subsection{The eighth branch 未 for Lamb on cross}

The eighth branch 未 $*$ represents 13:00-15:00, the initial time for Lamb to be nailed to wood 木 of cross. He 味 tasted bitter cup and then vinegar on the day in Matthew 27:34-45, Mark 15:22-33 and Luke 23:33-24:45. 味 味 flavor also has calf on firewood $*$ to match Leviticus 1-4. 昧 means darkness or lack of understanding, since “darkness came over all the land until the ninth hour", a lunar hour at the afternoon.

* 未 also resembles wood $\psi$ (木) to be voided $\times(一)$, and links to a fig tree withering in Matthew 21 and Mark 11. In Luke 23:27-31, "A large number of people followed Him, including women who mourned and wailed". Previously claiming His brothers and sisters 妹 as those who obeyed GOD, Jesus cited Hosea 10:8, "For the time will come when you will say, 'Blessed are the barren women, the wombs that never bore and the breasts that never nursed!" "For if men do these things when the tree is green, what will happen when it is dry?"

\subsection{The ninth branch 申 in crucifixion for GOD}

The ninth branch 申 皆 has the affix of GOD 神, and two hands in service in etymology. It represents 15:00-17:00, the time of final crucifixion of Jesus Christ, Son of GOD. In Luke 23:46 and Matthew 27:46, Jesus called out with a loud Voice, "FATHER, into YOUR HANDS I commit My Spirit." "About the ninth hour Jesus cried out in a loud Voice, "Eloi, Eloi, lama sabachthani?"- which means, "My GOD, My GOD, why have YOU forsaken Me?"' This indicates that GOD was determined for Jesus to bear all the pains in flesh. By allowing even HIS Son to be murdered on earth so miserably, GOD has shown to the whole world to allow sacrifice for any divine historical plan. Central structure of current writing of the three continuous earthly branches 午 $(11 \mathrm{am}-1 \mathrm{pm})$, 未 $(1-3 \mathrm{pm})$ and 申 $(3-5 \mathrm{pm})$ resembles cross 十, reflecting the length of time for Jesus' cross. 
學 can also represent divided curtain, as in Matthew 27:51 and Mark 15:38 "The curtain of the temple was torn in two from top to bottom." It resembles tricolor yarn $\exists$ of the curtain of tabernacle divided by a separation line. $\exists$ is an affix of textile due to the fact that biblical yarn of temple consists of scarlet, blue and purple threads. Cord is related to door 門 䀒 $\beta$ 甲 of tabernacle and courtyard made from the curtain, so that curtain is related to entry and entrance in biblical etymology.

\subsection{The tenth branch 西 for last supper}

The tenth earthly branch 西西 represents 17:00-19:00, the time of last supper in Matthew 26:27-29, Mark 14:23-25, and Luke 17-20, because 西 is liquid container such as jar of water and utensil of grape juice and wine 酒. After taking the cup, Jesus gave thanks and said, "Take this and divide it among you. For I tell you I will not drink again of the fruit of the vine until the kingdom of GOD comes." Thus, grape juice 汁 has cross 十 in every Easter's memorial ceremony 奠. To revere and venerate 尊畄 has to serve with perfume jar or the last supper jar 西, for priests or Jesus to obey 遵 GOD, when in John 14:31-15:17 "I love THE FATHER and do exactly what My FATHER has commanded Me". "This is My command: Love each other".

逼禗 to force and persecute shares identical affix with fortune and prosperity 福蝎, because in Matthew 5:10 "Blessed are those who are persecuted because of righteousness, for theirs is the kingdom of heaven." In Romans 12:12, "Bless those who persecute you". Persecute is psecurete, psecurity, when security secretly persecutes. When 富 the rich persecuted 逼, Jesus claimed that "blessed are the poor" in Matthew 5:9-6:24.

酒 wine is related to spouse 配, and wedding has wine because of at least three biblical events: Jesus' first miracle at Cana in a wedding to turn water to wine, wine served to Philistines in Samson's wedding, and Lot with his daughters by wine in Genesis 19:30. In John 2:3-11, "On the third day a wedding took place at Cana in Galilee." "Nearby stood six stone water jars, the kind used by the Jews for ceremonial washing, each holding from twenty to thirty gallons. Jesus said to the servants, "Fill the jars with water"; so they filled them to the brim. Then He told them, "Now draw some out and take it to the master of the banquet." They did so, and the master of the banquet tasted the water that had been turned into wine".

Jesus' bitter cup and priest's cup are also reflected by benefit 益 囸, liquid in cup. Liquid spilling over from such a cup is overflow 溢蹼. 谥 is posthumous title of saints or noble people. 缢 to hang has the bitter cup is and liquid $\equiv$, as in Matthew 26:14-27:9 and Mark 14:10-24 "He took the cup, gave thanks and offered it to them, saying, "Drink from it, all of you. This is My Blood of the covenant" and "Judas threw the money into the temple and left. Then he went away and hanged himself" for betraying innocent blood because of greed for money to murder. In this way to eat and treat Son is treason.

To betray is this tray of entree. Boy is to obey, but it is to disobey for boys to be killed by either Pharaoh or king Herod. To betray and treason are related words in biblical etymology, indicating that language is systematic divine design. Betrayal and treason are entree of Son, as in the last entree the traitor betrayed Jesus by greed of money.

The etymology of betrayal and treason, entree to eat, is also from Numbers 11:4-34 and Genesis 2-3. "THE ANGER OF THE LORD burned against the people" who were avid for food other than manna from heaven, so that 限 restrain is to restrict from eating 食 in trip 


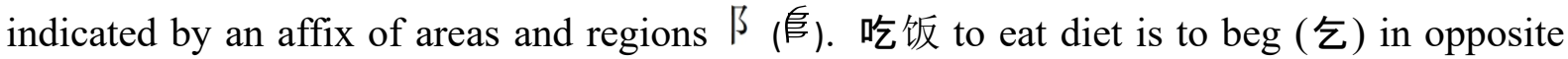
way or in rebellion (反 means to oppose or rebel), and treason (背叛) has $\curvearrowright$ flesh of wings of quail $火$. Death has to eat, as they "buried the people who had craved" food while eating quails. They should not have begged for unrestrained appetite, in analogy to forbidden fruit rather than fruits from all the other trees of Eden garden. In contrast, Abraham divided offering in halves 半 to worship THE DIVINITY in Genesis 15:10. To oppose (反) cutting offering to halves (半), i.e., not to cut near altar if such worship was known, would be to rebel 叛. To rebel is no (l) peer, not cut in pair. For millenniums, linguists were puzzled by why half rebellion is to rebel, but everyone should understand now: half not only mimics sound as previously hypothesized, but also represents the method of old testament worship, in turn symbolizing worship. Hence, not to worship is rebellion. Manna from heaven symbolizes Jesus Christ. 吃 to eat should be to pledge 乞 Christ for spiritual nutrient. "No one who comes to Me will ever go hungry. And no one who believes in Me will ever be thirsty." "Everyone who eats some of This Bread will live forever." This Bread is Holy Boy's Body.

Washing basin has sain of saint and sani of sanit, sanitary, sanitation, sanitarium, sanity and insane, and it is insane for priest not to wash in basin. The place of saint, synagogue, is sanguine sanitarium. Priests sink their hands and feet in water. With washing basin at sanctuary, sanction has sanit and saint, as unauthorized people will be put to death if getting too close to tabernacle, and priest will be sanctioned to death if not washed. In Numbers 1:50-52, "Instead, appoint the Levites to be in charge of the tabernacle of the Testimony" and "they are to take care of it and encamp around it." "Anyone else who goes near it shall be put to death”. 䊉制裁 sanction has to make 制 clothing 衣 after a tree, as in Genesis 3:21-24 "GOD made garments of skin for Adam and his wife and clothed them" and said, "He must not be allowed to reach out his hand and take also from the tree of life and eat, and live forever", so that sanction is to ban entry into sacred land. Sanguinary is with much bloodshed that "He is to wash the inner parts and legs with water". 潔 hygiene has water シ, when hydro is an affix of water in hydrogen, hydrophilic, hydrophobic, hydrocarbon, hydrochloric, hydroelectric, hydropathy, hydroplane, hydroponics, hydrant, hydraulic, hydraulics, hydrate and dehydration. Hydro is Hydra, sea serpent in Greek myth.

\subsection{The eleventh branch 戊 to arrest and defend Jesus}

The eleventh branch 戌 ' $f$ is hand $(F)$ to hold weapon $\mathbb{t}$, and represents 19:00-21:00, the precise time when "Simon Peter, who had a sword, drew it and struck the high priest's servant, cutting off his right ear. (The servant's name was Malchus.) Jesus commanded Peter, "put off your sword away! Shall I nor drink the cup THE FATHER has given Me?"” This branch also matches the weapons held by those who arrested Jesus.

\subsection{The twelfth branch 亥 for Son of Man 人 with cloud 云}

The twelfth branch 亥 represents 21:00-23:00, a time of claim as Son of GOD before Sanhedrin. In Matthew 26:63-64, the high priest said to Jesus, "I charge You under oath by THE LIVING GOD: Tell us if You are The Christ, The Son of GOD." "Yes, it is as you say," Jesus replied. "But I say to all of you: In the future you will see The Son of Man sitting at the right hand of THE MIGHTY ONE and coming on the clouds of heaven." 亥 is Son of Man or man with cloud. 亥 and Son 子 form 孩 Child. Son of Man and man are both related to cloud, 


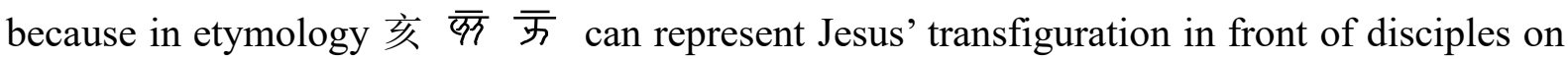
mountain, and has 云 cloud and 人 Man/man (Du 2019b). In Luke 9:32-35, “Two men, Moses and Elijah, appeared in glorious splendor, talking with Jesus. They spoke about His Departure, which He was about to bring to fulfill at Jerusalem." "While He was speaking, a cloud appeared and enveloped them". 31 can be considered as Moses and Elijah or His disciples. The three branches 亥，子 and 巳 reflect the time when Jesus claimed Himself as The Son or was cited by persecutors as so.

Words related to 亥 also match biblical etymology. 核 kernel has line (一) and curve 0

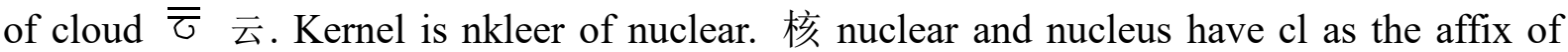
cloud $\bar{\tau}$. In multilingual match, nuclear, kernel and nebula have lne of line, and $\mathrm{c} / \mathrm{k} / \mathrm{u}$ as a curve, when cloud $\tau$ has double (doul) lines (l) and a curve (c). These indicate relative hieroglyphic feature of English. Stellar nebulae are full of nuclear reaction. An effect of radiation is apoptosis (programmed cell death), one of the many reasons why natural cancer is extremely rare, unless the mutation is purposely caused. This is consistent with Christ's law of love, as Jesus does not bring cancer. From scientific point of view, GOD can be too energetic that no one can see GOD directly and still live on earth. Apostles abundantly saw the physical as well as transfigured shining face of Jesus because Jesus is Son of GOD rather than GOD.

骇, terrible surprise, has 马 horse (manger) and Child 亥, because in Luke 2:4-20 angel said to shepherds, "Do not be afraid. I bring you good news of great joy that will be for all the people. Today in the town of David a Savior has been born to you; He is Christ The Lord. This will be a sign to you: You will find a Baby wrapped in cloths and lying in a manger."', 囯 manger has room 口 and 幸萃 fortunate shepherd大 and sheep 茟羊. 牧 shepherd is sheep herd 牛. In John 10:9-14, Jesus declares that "whoever enters through Me will be saved." "I Am The Good Shepherd; I know My sheep". To enter is to believe in heart, faith and action as christians, when Jesus definitively requires us to enter the narrow door of heavenly kingdom by effort. 擇 choice has good chance 幸, as The Shepherd is to choose through. 澤 mire, morass or marsh, has ram $¥$ and shepherd 士. 翻譯 translation has altar 田/ 口, and to interpret is between wings of two cherubim 坊 (inter pter). Pentecost has co pente, two birds of cherubim coincidentally.

骸 bone is nebo of nebula and has man 人 with nebula 云, also because of Ezekiel 37:1-11. "HE brought me out by THE SPIRIT OF THE LORD and set me in the middle of a valley; it was full of bones. HE led me back and forth among them, and I saw a great many bones on the floor of the valley, bones that were very dry. HE asked me, "son of man, can these bones live?"' HE said to me, "Prophesy to these bones and say to them, 'Dry bones, hear THE WORD OF THE LORD! This is what THE SOVEREIGN LORD says to these bones: I will make breath enter you, and you will come to life".

In Matthew 26, Luke 22 and John 19, Jesus was physically struck by soldiers and persecutors. 撞 collision at a location by relocated locomotive has loc, a root related to cloud $\bar{\tau}$. Location and relocation involve cloud, because of Exodus 40:36-38 and Numbers 9:15-10:13. "In all the travels of the Israelites, whenever the cloud lifted from above the tabernacle, they would set out; but if the cloud did not lift, they did not set out - until the day it lifted. So the cloud of THE LORD was over the tabernacle by day, and fire was in the cloud by night, in the sight of all the Israelites during all their travels." "Whether by day or by 
night, whenever the cloud lifted, they set out. Whether the cloud stayed over the tabernacle for two days or a month or a year, the Israelites would remain in camp and not set out; but when it lifted, they would set out. At THE LORD'S COMMAND they encamped, and at THE LORD'S COMMAND they set out", and "the cloud lifted from above the tabernacle of the covenant law. Then the Israelites set out from the Desert of Sinai and traveled from place to place until the cloud came to rest in the Desert of Paran". 鐘 clock matches 童 Child with cloud, since the 12 x 2 hours of earthly branches systematically match Son's crucifixion day. Because a Hebrew day starts from evening, the twelve branches form a daily cycle from the tenth branch 西 all the way around to the ninth branch 申 (西戌亥子丑寅卯辰巳午未申), from last supper to sacrifice for GOD on cross to fulfill predestined history.

\subsection{Additional etymology of twelve earthly branches from Abraham's sons}

Besides matching Jesus Christ as The Son in new testament, the twelve branches also match Abraham's two sons in old testament, despite of a wider match:

1) The first branch 子 $₹$ is Abraham's sons Isaac and Ishmael.

2) The second branch \# \# is to bind Isaac. In Genesis 22:3-13, “Abraham built an altar there and arranged the wood on it. He bound his son Isaac and laid him on the altar".

3) The third branch 寅 is to offer at Abraham's visited tent after divine promise of sons.

4) The forth branch 卯 is to shed blood in such offering.

5) The fifth branch 辰 is divinely promised pregnancy 娠 to Ishmael and Isaac. Its etymology is to forbid (represented by -) walking (represented by the footstep affix 歫) to a restricted tent $\digamma$, because in Genesis 16:6 "Sarah mistreated Hagar, so she fled".

6) The sixth branch 巳 represents a son from his own 己, as in Genesis 15:4 THE WORD OF THE LORD came to him: "a son coming from your own body will be your heir".

7) The seventh branch 午 $\uparrow \uparrow$ is to count stars, if you could count them, in the divine promise 许 about Ishmael.

8) The eighth branch 未 $*$ is offered ram on firewood that nullifies Isaac's death. "He went over and took the ram and sacrificed it as a burnt offering instead of his son."

9) The ninth branch 申 is VISIT OF GOD to Abraham or Abraham's worship to GOD.

10) The tenth branch 西 西 is water jar of Isaac's spouse 配. In Genesis 24:2-67, Abraham told his chief servant to "go to my country and my own relatives and get a wife for my son Isaac". The servant prayed that "May it be that when I say to a girl, 'Please let down your jar that I may have a drink,' and she says, 'Drink, and I'll water your camels too'-let her be the one you have chosen for your servant Isaac". Rebekah quickly lowered the jar to her hands and gave him a drink. His camels also drank.

11) The eleventh branch 戊 is Abraham's hand to hold knife to kill his son Isaac, or to hold weapon in battlefield to rescue others' sons and daughters.

12) The twelfth branch 亥 is child 孩 of Abraham. In Genesis 17:16-22, “I will bless her and will surely give you a son by her." "Yes, but your wife Sarah will bear you a son, and you will call him Isaac." GOD should ascend up in 云 cloud and cloud pillar after talking with the man 人一the etymology of child.

\section{Conclusion}

Twelve earthly branches are a major ancient calendar system in Asia, and have fascinated 
numerous linguists and archaeologists. Recently, the definitive etymology of its sibling calendar system, heavenly stem, was surprisingly discovered to match the seven divine days of Genesis. This article presents evidence that twelve earthly branches precisely match the crucifixion day of Jesus Christ, Son of GOD. These branches also match Abraham's two sons. The dual etymology of twelve earthly branches in both old and new testaments indicates indisputable divine creation of language.

\section{Acknowledgement}

We are grateful to GOD THE LORD, THE CREATOR of heavens and earth, with full gratitude in the highest respect.

\section{References}

Du, James X. 2019a. Seven days, numbers and heavenly Stems. International Journal of Linguistics 11/2.107-151. https://doi.org/10.5296/ijl.v11i2.14755

Du, James X. 2019b. Bilingual dissection of words with biblical correlation. International Journal of Language and Linguistics 7/1.50-54

Du, James X. 2020. Biblical etymology of organs and body parts. English Literature and Language Review 6/5.69-90. https://doi.org/10.32861/ellr.65.69.91

https://en.wikipedia.org

Ezekiel. 1st millennium B.C. Ezekiel

John. 1st century. John

Luke. 1st century. Luke

Mark. 1st century. Mark

Matthew. 1st century. Matthew

Moses. 2nd millennium B.C.a. Genesis

Moses. 2nd millennium B.C.b. Exodus

Moses. 2nd millennium B.C.c. Leviticus

Peter. 1st century. 1 Peter

Xu, Shen. 100-121 A.D. Analytical dictionary of characters 